\title{
Посмитная А.А. \\ Применение современных здоровьесберегающих технологий в системе дошкольного и начального образования
}

Омский Государственный Университет (Россия, Омск)

doi: $10.18411 / l j-25-12-2017-42$

idsp: 000001:lj-25-12-2017-42

\section{Аннотация}

В статье анализируется понятие «здоровьесберегающая технология», выделяются принципы использования здоровьесберегающих технологий в системе дошкольного и начального образования.

Ключевые слова: здоровьесбережение, здоровый образ жизни, технологии, здоровье дошкольника.

\section{Abstract}

The article analyzes the concept of "health-saving technology", emphasizes the principles of using health-saving technologies in the system of preschool and primary education

Key words: health saving, healthy lifestyle, technology, preschooler's health

В современной науке сложилось два подхода к пониманию здоровьесберегающих технологий в образовании:

1) здоровьесберегающая технология - это качественная характеристика любой образовательной технологии: оценивается уровень безопасности для здоровья конкретной технологии;

2) здоровьесберегающая технология - это набор принципов и методов (приемов) педагогической работы, дополняющие традиционные образовательные и воспитательные технологии, а также придающие им признак здоровьесбережения [3, с. 3236].

Обучение молодого поколения общим принципам укрепления здоровья, безусловно, является задачей, которую обязаны решать образовательные учреждения. Здесь подразумевается лишь общее, но подробное, ознакомление с основными современными системами и методами укрепления и охраны здоровья. В случае возникновения необходимости корректировки оздоровительной программы (например, индивидуальные особенности организма, либо восстановление уже пошатнувшегося здоровья), любой желающий может обратиться непосредственно к специалисту в области медицины (физиология, психология и т.п.).

Качественными диагностируемыми и проверяемыми характеристиками здоровья учащегося выступают:

- работоспособность ребенка (физическая и интеллектуальная);

- физическое развитие учащегося, его общая физическая подготовленность;

- уравновешенность и психологическая адекватность учащегося;

- совокупность социальных и духовных ценностей личности учащегося, обуславливающих общую культуру его поведения [2].

Цели здоровьесберегающих технологий всегда должны соотноситься с общими целями образования, которые в свою очередь отвечают требованиям времени и меняются в зависимости от потребностей общества. На сегодняшний день общей целью образования заключается в том, чтобы научить мыслить, работать, сформировать устойчивые качества творческой личности, способной к самореализации, и подготовить эту личность физически, психически и духовно к будущей самостоятельной жизни в систематически меняющихся условиях общества и окружающей среды. В таких условиях 
понимания целей образования здоровьесберегающая образовательная технология выступает в качестве функциональной системы способов организации и управления учебно-познавательной и практической деятельностью учащихся, которая научно и инструментально обеспечивает сохранение или укрепление здоровья детей.

Здоровьесберегающая концепция обеспечивает понимание важности технологического подхода к образовательному процессу, как реально гуманнонравственной деятельности.

Базовые технологические принципы разработки здоровьесберегающей образовательной системы:

- единство связи основных элементов системы здоровьесберегающей образовательной технологии: информационная, инструментальная и кадровая составляющие не только взаимосвязаны, но и взаимозависимы (малейшее изменение одной из составляющих обязательно повлечет за собой потребность в корректировке двух оставшихся);

- диагностичность целеполагания здоровьесберегающей образовательной технологии;

- функциональная полнота и взаимосвязь содержания здоровьесберегающей технологии - полноценная ее реализация возможна, если:

a) охватываются одновременно все основные составляющие здоровьесберегающей системы;

б) формируются все признаки и качества культуры здорового образа жизни и, в частности, физической культуры;

в) представление, изучение и освоение содержания здоровьесберегающей технологии реализуется посредством использования строго конкретных формализованных методов с соблюдением конкретных условий и в конкретной форме;

- открытость функциональных и методических действий: вся деятельность по внедрению и становлению здоровьесберегающей образовательной системы должна быть предельно понятной, логически обоснованной и информационно открытой и для учащихся, и для педагогов;

- объективная оценка конечного результата: только этому может быть осуществлен продуктивный контроль результатов, а соответственно последующая коррекция, поиск и исправление потенциально допущенных ошибок;

- преемственность и завершенность: содержание здоровьесберегающей образовательной технологии должно быть не только самосогласовано, но и согласовано с технологической моделью и различными формами учебной деятельности на всех ступенях образования в макро- и микроструктуре;

- вариативность средств, методов и организационных форм внедрения здоровьесберегающих технологий в образовании: широкий и разнообразный спектр средств, методик, методов, форм и видов здоровьесберегающих образовательных технологий, по сути, обеспечивает целостность и полноценность всей образовательной системы;

- оптимизация: в каждом конкретном рассматриваемом случае необходимо выбирать актуально лучший план деятельности, т.е. наилучший вариант [1, с. 15].

Классификация здоровьесберегающих технологий в дошкольном образовании определяется по доминированию целей и решаемых задач, а также ведущих средств здоровьесбережения и здоровьеобогащения педагогического процесса в детском саду. В связи с этим можно выделить следующие виды здоровьесберегающих технологий: 
Медико-профилактические технологии, обеспечивающие сохранение и приумножение здоровья детей под руководством медицинского персонала детского сада в соответствии с медицинскими требованиями и нормами, с использованием медицинских средств.

Физкультурно-оздоровительные технологии, направленные на физическое развитие и укрепление здоровья ребенка: развитие физических качеств, двигательной активности и становление физической культуры дошкольников, закаливание, дыхательная гимнастика, массаж и самомассаж, профилактика плоскостопия и формирование правильной осанки, оздоровительные процедуры в водной среде (бассейне) и на тренажерах, воспитание привычки к повседневной физической активности и заботе о здоровье и реализация этих технологий, как правило, осуществляется специалистами по физическому воспитанию и воспитателями в условиях специально организованных форм оздоровительной работы.

Технологии обеспечения социально-психологического благополучия ребенка, обеспечивающие психическое и социальное здоровье дошкольника.

Технологии здоровьесбережения и здоровьеобогащения педагогов дошкольного образования, направленные на развитие культуры здоровья педагогов детского сада, в том числе культуры профессионального здоровья, развитие потребности к здоровому образу жизни [2].

В целом можно констатировать, что здоровьесберегающая технология - это система, объединяющая в себе широкий спектр психолого-педагогических и организационно-функциональных установок, предполагающих многовариантную компоновку методов, приемов, форм, образовательно-воспитательных средств и процедур, которые на практике обеспечивают интеграцию учащегося в подготовленную среду. Данная технологически организованная система ориентирована на вполне конкретный педагогический целевой результат - высокий уровень здоровья дошкольников и учащихся начальной школы, а также креативное взращивание культуры их здорового образа жизни.

$$
* * *
$$

1. Источник №1 Иванова С.С. Здоровьесберегающая среда в ДОУ как фактор внедрения ФГОС ДО // Теория и практика образования в современном мире: материалы VII Междунар. науч. конф. (г. СанктПетербург, июль 2015 г.). - СПб.: Свое издательство, 2015. - С. 14-16.

2. Источник №2 Крылова М.А. Анализ современных здоровьесберегающих технологий в дошкольном образовании // Научное сообщество студентов ХХІ столетия. ГУМАНИТАРНЫЕ НАУКИ: сб. ст. по мат. XLIV междунар. студ. науч.-практ. конф. № 7(44). [электронный ресурс] - Режим доступа. - URL: https://sibac.info/archive/guman/7(44).pdf

3. Источник №3 Тюшникова А.Г. Повышение качества образования через использование здоровьесберегающих технологий // Научно-методический электронный журнал «Концепт». 2013. Т. 3. - C. $3236-3240$.

\section{Саморокова C.A. \\ К актуальности проблемы управления методической работой педагогов в современной детской школе искусств средствами мониторинга}

Нижневартовский государственный университет (Россия, Нижневартовск)

doi: $10.18411 / l j-25-12-2017-43$

idsp: 000001:lj-25-12-2017-43

Аннотация

В статье на основе современных подходов в менеджменте предпринимается попытка изучения мониторинга как средства управления методической работой педагогов в детской школе искусств. Методическая работа рассматривается как систематическая 